\title{
Carbon fluxes of surfaces vs. ecosystems: advantages of measuring eddy covariance and soil respiration simultaneously in dry grassland ecosystems
}

\author{
Z. Nagy ${ }^{1,2}$, K. Pintér ${ }^{1}$, M. Pavelka ${ }^{3}$, E. Darenová ${ }^{3}$, and J. Balogh ${ }^{1}$ \\ ${ }^{1}$ Plant Ecology Research Group of Hungarian Academy of Sciences, Szent István University, Páter u. 1., 2103 Gödöllõ, \\ Hungary \\ ${ }^{2}$ Institute of Botany and Ecophysiology, Szent István University, Páter u. 1., 2103 Gödöllõ, Hungary \\ ${ }^{3}$ Global Change Research Centre AS CR, v.v. i. Belidla 4a 60300 Brno, Czech Republic
}

Received: 26 January 2011 - Published in Biogeosciences Discuss.: 4 February 2011

Revised: 10 August 2011 - Accepted: 24 August 2011 - Published: 9 September 2011

\begin{abstract}
An automated open system for measurement of soil $\mathrm{CO}_{2}$ efflux $\left(R_{\mathrm{sc}}\right)$ was developed and calibrated against known fluxes. The system was tested in the field, while estimating soil respiration simultaneously by the gradient method $\left(R_{\mathrm{sg}}\right)$ at a dry, sandy grassland site (Bugac, Hungary). Ecosystem respiration $\left(R_{\text {eco }}\right)$ was measured using the eddy covariance technique. The small chamber size $(5 \mathrm{~cm}$ in diameter) made it possible to use the chambers in vegetation gaps, thereby avoiding the necessity of removing shoots and disturbing the spatial structure of vegetation and the upper soil layer. Low air flow rates associated with small chamber volume and chamber design allowed the overpressure range to stabilize between $0.05-0.12 \mathrm{~Pa}$. The correlation between ecosystem and soil $\mathrm{CO}_{2}$ efflux rates as measured by the independent methods was significant, $R_{\text {eco }}$ rates were similar or even lower than $R_{\mathrm{sc}}$ in the low flux (up to $2 \mu \mathrm{mol} \mathrm{CO} \mathrm{CO}_{2} \mathrm{~m}^{-2} \mathrm{~s}^{-1}$ ) range but the differences were within the uncertainty limits for the two fluxes. $R_{\mathrm{sc}}$ from trenched and non-trenched plots amounted to $16 \%$ and $44 \%$ of $R_{\text {eco }}$, respectively. The gradient method showed both up and downward $\mathrm{CO}_{2}$ fluxes originating from the main rooting zone after rains. Diffusive retardation played a smaller role than $\mathrm{CO}_{2}$ production considering the soil air $\mathrm{CO}_{2}$ concentration increase after rains in a given layer. Downward fluxes within the soil profile amounted to $15 \%$ of the simultaneous upward fluxes and to $\sim 7.6 \%$ of the total (upward) effluxes during the 3-month study. The upper $5 \mathrm{~cm}$ soil layer contributed to $\sim 50 \%$ of the total soil $\mathrm{CO}_{2}$ efflux. Downward fluxes are expected to seriously affect (1) the $R_{\text {eco }}$ vs. temperature response functions and (2) the net ecosystem exchange
\end{abstract}

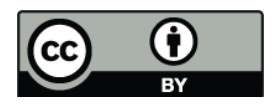

Correspondence to: Z. Nagy

(nagy.zoltan@mkk.szie.hu) of $\mathrm{CO}_{2}$ (NEE) vs. photon flux density response functions, therefore potentially affecting the gap filling procedures and to lead to a situation (3) when the measured surface and the real time ecosystem fluxes will necessarily differ in the short term. Simultaneous measurements of $R_{\text {eco }}$ and soil $\mathrm{CO}_{2}$ effluxes may reveal the timing and magnitude of the decoupling, thereby contributing to decreasing uncertainty associated with eddy flux measurements over flat terrains. While the correlations between $\mathrm{CO}_{2}$ effluxes measured by independent systems are strong, $R_{\mathrm{sg}}$ was generally larger than $R_{\mathrm{sc}}$ or $R_{\text {eco }}$, mainly due to overestimation of effective diffusivity in the soil.

\section{Introduction}

The emission of $\mathrm{CO}_{2}$ from the soil surface $\left(R_{\mathrm{S}}\right)$ represents the largest fraction (60-80\%) of ecosystem respiration (Raich and Schlesinger, 1992; Janssens et al., 2002; Luo and Zhou 2006). Currently, most of the commercially available systems for $R_{\mathrm{S}}$ measurements use chambers with a diameter of $10 \mathrm{~cm}$ or greater. This size often necessitates the removal of aboveground plant biomass, especially in closed grasslands, where the average gap size between tussocks is $<10 \mathrm{~cm}$. Removal of above-ground biomass prior to taking measurements (usually $24 \mathrm{~h}$ before the measurements, Bahn et al., 2008) is a serious intervention, as it destroys the spatial structure of the vegetation, which can influence vegetation dynamics (Hook et al., 1994). Cutting and biomass removal affects radiation at the surface, soil temperature and moisture, increases plant stress and disrupts the photosynthate supply to roots and rhizospheric microbes (Tang et al., 2005a; Cao et al., 2004).

Published by Copernicus Publications on behalf of the European Geosciences Union. 
Despite their simple design and ease of operation, open soil respiration systems are not widely used (Iritz et al., 1997; Fang and Moncrieff, 1996, 1998). The main problem with this configuration is caused by the pressure difference between the chamber and the ambient air, often caused by the applied high flow rates. Any pressure differences larger than one-fifth of a Pa can seriously affect the measured $\mathrm{CO}_{2}$ efflux (Fang and Moncrieff, 1998; Smith et al., 2010). Serious changes in environmental conditions above the soil surface in the chambers (decreased boundary layer caused by high flow rates, very low or very high $\mathrm{CO}_{2}$ concentrations, etc.) should also be avoided during the measurement period (Subke et al., 2004).

Our first aim was to develop a new, simple, cost-effective open system suitable for soil $\mathrm{CO}_{2}$ efflux measurements fulfilling the following criteria:

- Minimizes modification to environmental respiration drivers through small chamber diameter, reduced insertion depth and no collars (i.e. Wang et al., 2005).

- Avoids disturbance to the current photosynthetic supply to the root zone. Larger chamber diameters fail to meet this criterion due to the regular cutting/weeding needed, in addition to the initial disturbance caused by system setup.

- Allows water to enter through the vent holes on the top (precipitation events) and from the perimeter (base) toward the center of the chamber. Water transport is supposed to be adequate over the $2.5 \mathrm{~cm}$ distance (radius of the chamber) range.

- Serves as a tool for continuous automatic measurement of soil $\mathrm{CO}_{2}$ efflux, capable of operating for long periods when unattended.

The second goal of the study was to compare the soil $\mathrm{CO}_{2}$ efflux rates as measured by the chamber method with $R_{\text {eco }}$ from eddy-covariance measurements in an effort to address the previously reported problem of similar or higher $R_{\mathrm{S}}$ than $R_{\text {eco }}$ values (Goulden et al., 1996; van Gorsel et al., 2007, Myklebust et al., 2008). In the present study we sought to contribute to decreasing the uncertainty arising from typical nighttime limitations in eddy flux measurements over flat terrain (Massman and Lee, 2002; Smith et al., 2010).

A third goal of the study was to investigate soil respiration dynamics by the gradient method within the soil profile after rainstorms, as a significant percentage of the total $\mathrm{CO}_{2}$ fluxes occur during these events in drought-prone grasslands ecosystems (Xu et al., 2004). Information leading to better characterization of fluxes during these periods may contribute to improved models of soil respiration and decreasing uncertainty of $\mathrm{CO}_{2}$ balance estimates.
Table 1. Depths of sampled soil layers for computations of bulk densities, air filled porosity, the tortuosity factor (as used in Eqs. 1 and 2), the average soil organic matter content (in $\mathrm{gC} \mathrm{kg}^{-1}$ dry soil) at the different depths.

\begin{tabular}{lccccc}
\hline $\begin{array}{l}\text { Layers } \\
\text { measured }\end{array}$ & $\begin{array}{c}\text { reference } \\
\text { depths }(\mathrm{cm})\end{array}$ & $\begin{array}{c}\rho_{\mathrm{b}} \\
\left(\mathrm{g} \mathrm{cm}^{-3}\right)\end{array}$ & $\eta$ & $S$ & Corg g kg $^{-1}$ \\
\hline Upper & $0-5$ & 1.18 & 0.554 & 0.87 & 51.5 \\
Mid & $10-20$ & 1.35 & 0.491 & 0.91 & 20.3 \\
Lower & $30-50$ & 1.44 & 0.457 & 0.94 & 3.8 \\
\hline
\end{tabular}

\section{Materials and methods}

\subsection{Site description}

The study site (Bugac, $46.69^{\circ} \mathrm{N}, 19.6^{\circ} \mathrm{E}, 114 \mathrm{~m}$ a.s.l.) is situated in a pasture of $550 \mathrm{ha}$, with a chernozem type sandy soil with high organic carbon content (Table 1). The average annual precipitation is $562 \mathrm{~mm}$ (10 year average, 1995-2004), annual mean temperature is $10.4^{\circ} \mathrm{C}$. Main plant species include Festuca pseudovina Hack. ex Wiesb., Dactyliy glomerata L., Elymus repens L., Carex stenophylla Wahlbg. and Salvia pratensis L., the total species number exceeds 80 . The study site is a part of the Kiskunság National Park and has been under extensive management (low grazing pressure) for the last 20 years. $\mathrm{CO}_{2}$ flux measurements (continuous eddy covariance and occasional soil respiration measurements) have been started in 2002 (Nagy et al., 2007; Balogh et al., 2011).

\subsection{Soil respiration measurements by the automated open system}

The system consists of an infrared gas analyzer SBA-4 (PPSystems, UK, IRGA), two pumps (MP, P), mass flow meters (MFM, type D6F-01A1-110, Omron Co. Kyoto, Japan), electric valves (V1-4) and four PVC-metal soil chambers (Fig. 1). The main pump of the system (Eheim 400, Eheim, Germany, MP) is situated in a 21 buffer volume. The chambers are $10.4 \mathrm{~cm}$ high with a diameter of $5 \mathrm{~cm}$, and an area covering approximately $19.6 \mathrm{~cm}^{2}$ of the soil surface. The PVC chambers (C) are enclosed in a white metal cylinder with $2 \mathrm{~mm}$ airspace in between to stabilize the chamber and to prevent warming by direct radiation. Four vent holes with a total area of $0.95 \mathrm{~cm}^{2}$ were drilled in the top of the chambers. Vent holes also served to allow precipitation into the chambers.

The reference air flow from the main pump is divided into two ways: one stream goes to the IRGA, the other through MFMs into the chambers at a flow rate of $220-240 \mathrm{ml} \mathrm{min}^{-1}$ (as measured by MFMs). The inlet of the reference air flow is positioned at the lower part of the chamber, $1 \mathrm{~cm}$ above the soil surface. Air from the funnel in the chamber is sampled 


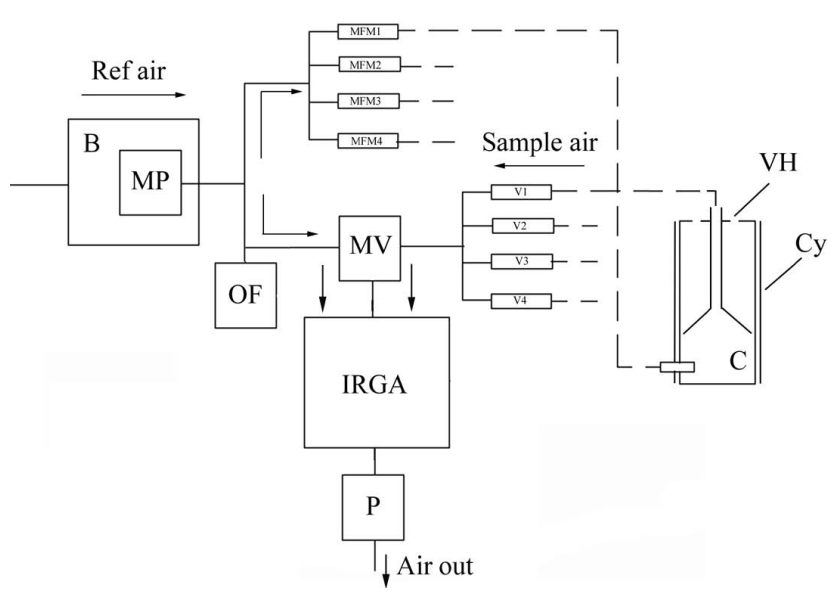

Fig. 1. Schematic air-flow diagram of the system (B: buffer volume, MP: main pump, P: sampling pump, OF: overflow, MFM1-4: mass flowmeters, MV: main valve, V1-4: valves, VH: vent holes, $\mathrm{C}$ : chamber with a funnel, $\mathrm{Cy}$ : metal cylinder, IRGA: gas analyzer, Ref air: reference air flow, Sample air: sample air flow, Air out: air outlet from the system).

by a pump (P) with a flow rate of $160-180 \mathrm{ml} \mathrm{min}^{-1}$ and then guided to the same IRGA. Measuring both the reference and the analysis cycle took $14 \mathrm{~s}$, including also the necessary purge times. The system works as an open steadystate system (Fig. 1). No in-soil base collars were used with the chambers; the sharpened chamber base was inserted directly into the soil to a depth of $\sim 3-5 \mathrm{~mm}$, thereby avoiding deeper disturbance of the soil (Wang et al., 2005). The system was controlled using software written to operate a data logger CR23X (Campbell Sci., UK), control timing of measurements on a particular chamber, switch valves, measure the signals from the MFMs, the IRGA and other sensors (see below) and also to store data. Air and soil temperature sensors, a soil moisture sensor (thermocouples and CS616 water content reflectometer, Campbell Sci., UK) and a pressure sensor (SDP1000-L05, Sensirion AG, Staefa, Switzerland) were used to measure pressure difference between the chamber and the ambient air, and were also attached to the datalogger. Low air flow rates, small chamber volume, chamber design (relatively large tube diameters, vent holes on the top of the chambers, inner funnel dimensions) stabilized the overpressure range between $0.05-0.12 \mathrm{~Pa}$.

The system's parts (datalogger, IRGA, valves, air flow meters, pumps etc) were built into a waterproof box. The system was programmed using the Edlog software (Campbell Sci., UK) to make measurements during one half-hour period every two hours during the field measurements. Data from each chamber was measured for $3 \mathrm{~min}$, by saving the average of the $\mathrm{CO}_{2}$-concentrations in the last minute. Average values of further variables (air flow rates, air and soil temperatures, soil water content, pressure differential between the chamber and the ambient air) were also saved at the same time.
Development, calibration and field test of the system were performed during 2007 and 2008 and the final version of the system was implemented during the summer of 2009.

\subsection{Gradient method}

Three GMP343 (Vaisala, Finland) IRGAs were inserted into the soil at depths of 5,12 and $35 \mathrm{~cm}$, respectively, within $3 \mathrm{~m}$ of the eddy station and within 1-2 $\mathrm{m}$ of the soil respiration chambers. The sensors were sampled by the CR5000 (Campbell, UK) data logger (which also controlled eddy measurements) at 10-s intervals and averaged half-hourly. Soil temperatures and soil (volumetric) water contents were measured and stored at the same time interval. An $0.6 \mathrm{~m}$-deep ditch was dug, and sensors were inserted into the ditch wall at the previously-listed depths before the soil was replaced. Much attention was paid to avoiding disturbing the soil structure where the sensors had been inserted, and soil layers were packed back into the ditch in the same order as they had been removed.

The gradient method was applied to estimate fluxes using the diffusion model as reported previously (e.g. Tang et al., 2003, 2005a; Moldrup et al., 1999; Myklebust et al., 2008), calculating the flux $(F)$ as:

$F=\frac{K}{\Delta z} \cdot\left(C_{2}-C_{1}\right)$

$K=D_{\mathrm{CO}_{2}, \text { air }} \cdot \frac{(\eta-\mathrm{SWC})^{2.9 \cdot S}}{\eta}$

with $F$ being the soil $\mathrm{CO}_{2}$ efflux (in $\mu \mathrm{mol} \mathrm{CO}_{2} \mathrm{~m}^{-2} \mathrm{~s}^{-1}$ ), $C$ the $\mathrm{CO}_{2}$ concentration measured at $15 \mathrm{~cm}$ height from the surface (in $\mu \mathrm{mol} \mathrm{CO}_{2} \mathrm{~m}^{-3}$ ), $K$ the diffusion coefficient between the soil layers at distance $\Delta z(\mathrm{~m}), D_{\mathrm{CO}_{2} \text { air }}$ the diffusivity for $\mathrm{CO}_{2}$ in air, with its value taken as $1.47 \times 10^{-5} \mathrm{~m}^{2} \mathrm{~s}^{-1}$ multiplied by $(\mathrm{T} / 293.2)^{1.75}$ (Jones 1992), $\eta$ the air-filled porosity of dry soil (fraction), SWC the volumetric soil water content at the particular depth (fraction), with $\eta$ calculated as $\eta=\left(\rho_{\mathrm{s}}-\rho_{\mathrm{b}}\right) / \rho_{\mathrm{s}}$. where $\rho_{\mathrm{s}}$ is the density of the mineral soil $\left(2.65 \mathrm{Mg} \mathrm{m}^{-3}\right)$, while bulk densities $\left(\rho_{\mathrm{b}}\right)$ of the soil layers considered are listed in Table 1, as well as values of $S$ (tortuosity factor), given by the sum of silt and clay fractions. Fluxes between the soil layers were also calculated as described above.

\subsection{The eddy covariance setup}

The basic eddy covariance system at the Bugac site consists of a CSAT3 sonic anemometer (Campbell, USA) and a Li-7500 (Licor Inc, USA) open path IRGA both connected to a CR5000 logger (Campbell, USA). Additional measurements (e.g. temperature, precipitation, global radiation) were performed as described in Nagy et al. (2007) and Pintér et al. (2008). Fluxes of sensible and latent heat and $\mathrm{CO}_{2}$ were processed using an IDL program after Barcza et al. (2003), 
adopting the CarboEurope IP methodology. Spikes in the raw $(10 \mathrm{~Hz})$ wind speed, $\mathrm{H}_{2} \mathrm{O}$ and $\mathrm{CO}_{2}$ concentration data caused by electric malfunctions or dew formation were detected and removed after Vickers and Mahrt (1997). Systematic error caused by the possible inaccurate leveling of the sonic anemometer was corrected by the planar fit method (Wilczak et al., 2001). Linear detrending was also performed on the raw data. Errors caused by the large angle of attack were avoided by the method described in van der Molen et al. (2004). The effects of density fluctuations on the turbulent fluxes were corrected by the method described in Webb et al. (1980). Damping effect of the sensor line averaging and the limited response time of the anemometer and the gas analyzer were corrected by Moore (1986). Storage term calculated from the rate of change in $\mathrm{CO}_{2}$ concentration below the measuring level (Flanagan et al., 2002) was used to correct half-hourly $\mathrm{CO}_{2}$ fluxes. When comparing to soil respiration values only nighttime, storage corrected (Aubinet et al., 2001) values of $R_{\text {eco }}$ with $u^{*}$ higher than $0.1 \mathrm{~m} \mathrm{~s}^{-1}$ were used.

\subsection{Uncertainty analysis}

Random measurement error of EC and chamber measurements was quantified using pairs of independent flux measurements under identical conditions after Hollinger and Richardson (2005). Environmental conditions were considered identical if the difference between half-hourly PAR, temperature and windspeed data in the same time of day on consecutive days were less than $75 \mu \mathrm{mol} \mathrm{m}{ }^{-2} \mathrm{~s}^{-1}, 3{ }^{\circ} \mathrm{C}$ and $1 \mathrm{~ms}^{-1}$, respectively. Uncertainty $(U)$ of a given flux was estimated as the standard deviation $(\sigma)$ of the difference between the paired fluxes.

$U=\frac{1}{\sqrt{2}} \sigma\left(X_{1}-X_{2}\right)$,

where $\mathrm{X}_{1}$ and $\mathrm{X}_{2}$ are the paired $\mathrm{EC}$ or chamber fluxes meeting the above criteria.

\subsection{Tests of the automated soil respiration measurement system}

Performance of the new system was checked by (1) calibration of the system against $\mathrm{CO}_{2}$ fluxes estimated independently and (2) testing the system in the field under continuous, unattended operating conditions.

\subsubsection{Calibration}

Calibration of the new system was carried out in a calibration tank, made after Pumpanen et al. (2004) at Global Change Research Centre in Brno. The calibration tank is cylindrical, $1.13 \mathrm{~m}$ in diameter and $1.08 \mathrm{~m}$ in height. The internal volume of the tank is $1.08 \mathrm{~m}^{3}$, with a calibration area of $1.00 \mathrm{~m}^{2}$, designed as a $0.12 \mathrm{~m}$-thick layer of pure quartz sand placed on perforated partitions. An air pump drew the air sample

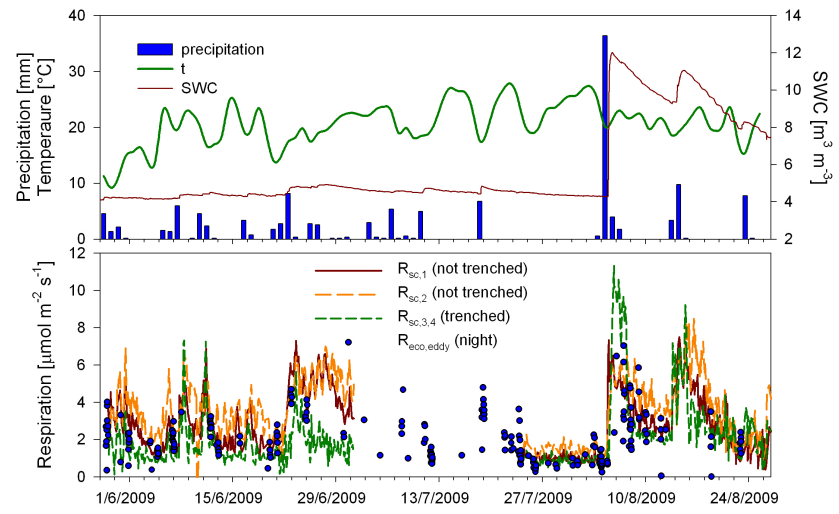

Fig. 2. Time courses of $R_{\text {eco }}$ (nighttime, storage corrected, $u^{*}$ filtered (threshold: $0.1 \mathrm{~m} \mathrm{~s}^{-1}$ )) EC data, $R_{\mathrm{sc}}$ from chambers placed in vegetation gaps (not trenched) and from the trenched plots (lower panel) and precipitation (upper panel left axis), daily average temperature (left axis) and volumetric soil water content (right axis) in the upper $30 \mathrm{~cm}$ of the soil during summer, 2009 at Bugac site. Lack of $R_{\mathrm{Sc}}$ data (middle of the graph) was caused by disruptions in the electricity supply.

from the tank into the infrared gas analyzer (Li-820, Li-Cor, U.S.A., equipped with the 5 -cm long sample cell enabling it to measure $\mathrm{CO}_{2}$ concentration up to $20000 \mathrm{ppm}$ ) and blew it back to the tank. The analyzer was connected to a DL-3000 data logger (Delta-T Devices, U.K.). Concentration of $\mathrm{CO}_{2}$ inside the tank was measured and logged every 15 minutes. Measured data were fitted by a Chebyshev Rational Order $5 / 6$ function (using software TableCurve 2D, Systat, USA). $\mathrm{CO}_{2}$ efflux from the tank was calculated as in Pumpanen et al. (2004). The Chebyshev function fitted measured data better than the theoretically expected exponential function. The differences between fluxes calculated from the two fits, Chebyshev and exponential, were smaller than $2 \%$ and were caused by not totally constant conditions in the room with calibration tank (air pressure and temperature mainly).

\subsubsection{Field test}

The system was set up after performing the calibration at Bugac, Hungary (Pintér et al., 2008) for 4 months to test it under different meteorological conditions and continuous operation. Two chambers were placed in vegetation gaps, and another two in a trenched plot. Trenches were established in autumn of 2007, by removing all living roots from a $0.4 \mathrm{~m} \times 0.6 \mathrm{~m}$ plot to $0.4 \mathrm{~m}$ depth, replacing the soil, and applying plexiglass sheets to $0.5 \mathrm{~m}$ depth at the sides to prevent root ingrowths. During the 4 month period, the system remained operational despite high temperatures (exceeding $38^{\circ} \mathrm{C}$ ) and rainstorms (Fig. 2), except for failures in electricity supply. 
Table 2. Slopes, standard error of slopes and determination coefficients $\left(r^{2}\right)$ of linear regressions constrained through the origin (model $y=m x$ ) between the "true" $\mathrm{CO}_{2}$ effluxes (the efflux as calculated for the calibration tank) and the efflux rates as measured by the chambers of the new system (Ch1...Ch4). The slopes were used later on (during evaluation of field measurements) as calibration coefficients.

\begin{tabular}{lcccc}
\hline & ch1 & ch2 & ch3 & ch4 \\
\hline slope & 1.05 & 0.99 & 0.95 & 0.93 \\
SE of slope & 0.0068 & 0.0052 & 0.0059 & 0.0047 \\
$r^{2}$ & 0.967 & 0.969 & 0.955 & 0.934 \\
\hline
\end{tabular}

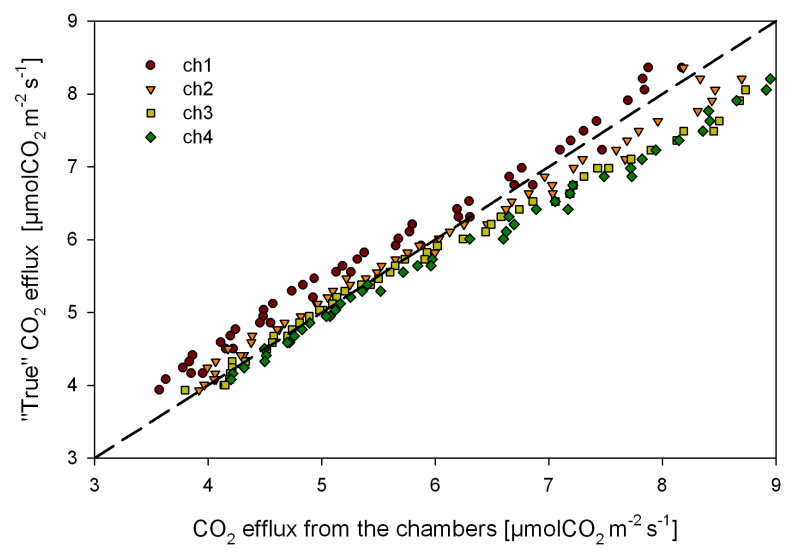

Fig. 3. $\mathrm{CO}_{2}$ fluxes from the calibration tank ("true" $\mathrm{CO}_{2}$ efflux) vs. the fluxes as measured by the four chambers (ch1-4) of the soil respiration system. The 1:1 line is shown (dashed line).

\section{Results}

\subsection{Calibration of the chambers of the automated soil respiration system}

The system was calibrated after checking for zero fluxes (i.e. by measuring a glass plate) against effluxes from a calibration tank. The agreement between the systems' fluxes is characterized by $r^{2}$ values of linear fit between 0.934 and 0.969 (by constraining the regression through the origin, Table 2), for fluxes within the range of 3.5$9 \mu \mathrm{mol} \mathrm{CO} \mathrm{m}^{-2} \mathrm{~s}^{-1}$ (Fig. 3). Slopes were applied afterwards as calibration coefficients when calculating the fluxes during the field test.

\subsection{Field test of the automated soil $\mathrm{CO}_{2}$ efflux chamber system}

Results from the continuously-operating field chamber system demonstrated that the two chambers placed in vegetation gaps measured similar or higher values of soil respiration than nighttime NEE $\left(R_{\text {eco }}\right)$, measured by the eddy covariance

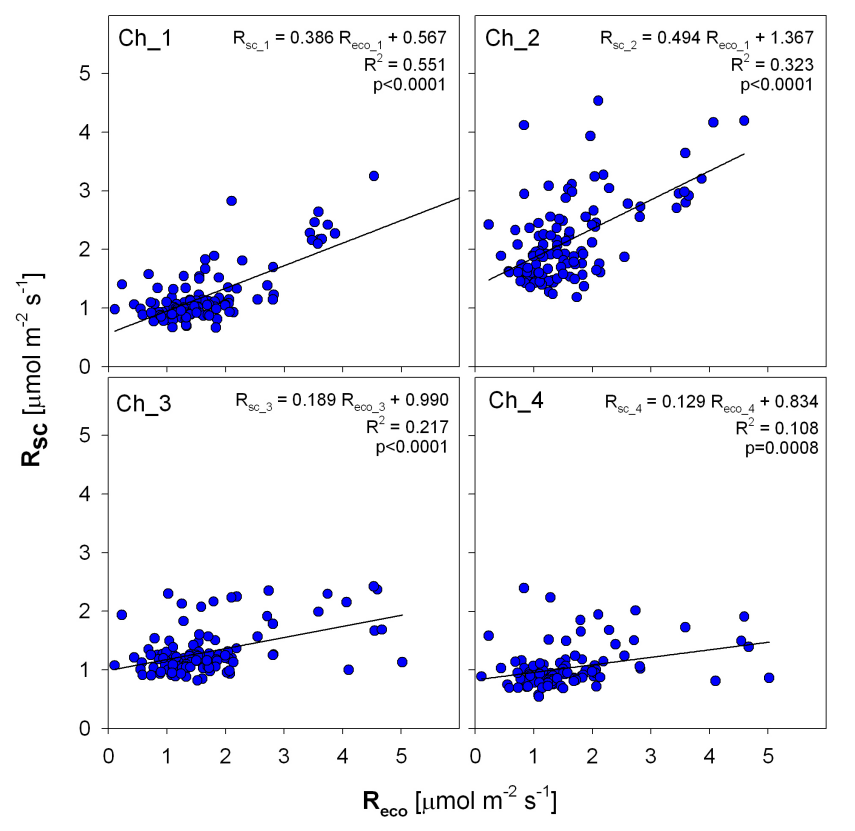

Fig. 4. Regressions between soil respiration $\left(R_{\mathrm{Sc}}\right)$ and ecosystem respiration $\left(R_{\mathrm{eco}}\right)$ rates as measured during nights by the automated open (chamber) system, and the eddy technique, respectively. Data for chambers in vegetation gaps (Ch1 and $\mathrm{Ch} 2)$ and trenched plots (Ch3 and Ch4) are shown. Only original (not gapfilled) storage corrected and $u^{*}$-filtered $\left(u^{*}>0.1 \mathrm{~m} \mathrm{~s}^{-1}\right)$ eddy data (half hourly averages) and $R_{\mathrm{sc}}$ data with pressure difference (between the chambers' headspace and the ambient air) less than $0.15 \mathrm{~Pa}$ were used in the analyis.

Table 3. Statistical parameters for the regression between chamber (ch1-ch4) vs EC $\left(R_{\text {eco }}\right)$ fluxes.

\begin{tabular}{ccccccc}
\hline \multicolumn{4}{c}{ Regression } & \multicolumn{2}{c}{ Standard Error } & \multicolumn{2}{c}{$P$} \\
\hline & slope & intercept & slope & intercept & slope & intercept \\
ch1 & 0.386 & 0.567 & 0.033 & 0.063 & $<0.0001$ & $<0.0001$ \\
ch2 & 0.494 & 1.367 & 0.069 & 0.124 & $<0.0001$ & $<0.0001$ \\
ch3 & 0.189 & 0.990 & 0.034 & 0.064 & $<0.0001$ & $<0.0001$ \\
ch4 & 0.129 & 0.834 & 0.037 & 0.067 & 0.0008 & $<0.0001$ \\
\hline
\end{tabular}

technique (Figs. 2 and Fig. 4) in the low flux ranges. As NEE data have been $u^{*}$ filtered, storage was small (in the order of $0.01 \mu \mathrm{mol} \mathrm{CO} \mathrm{CO}^{-2} \mathrm{~s}^{-1}$ ) in these cases, although it is significant at the site during (quite frequent) conditions of low turbulence. While the intercepts on Fig. 4 are significantly higher than zero (Table 3), flux uncertainties (considering both eddy and chamber fluxes, Table 4) were large enough to consider the differences (intercepts) insignificant.

$R_{\mathrm{Sc}}$ from the trenched plot were generally lower than $R_{\mathrm{sc}}$ from the chambers placed within natural vegetation gaps (between grass tufts). This picture was different after rain events, when chambers in the trenched plots measured 
Table 4. Uncertainty values for the EC fluxes and the chamber measurements.

\begin{tabular}{lc}
\hline & Uncertainty \\
\hline & $\left(\mu \mathrm{mol} \mathrm{CO} \mathrm{m}^{-2} \mathrm{~s}^{-1}\right)$ \\
$\mathrm{ch} 1$ & 0.594 \\
$\mathrm{ch} 2$ & 0.328 \\
$\mathrm{ch} 3$ & 1.065 \\
$\mathrm{ch} 4$ & 1.706 \\
$\mathrm{EC}$ & 1.011 \\
\hline
\end{tabular}

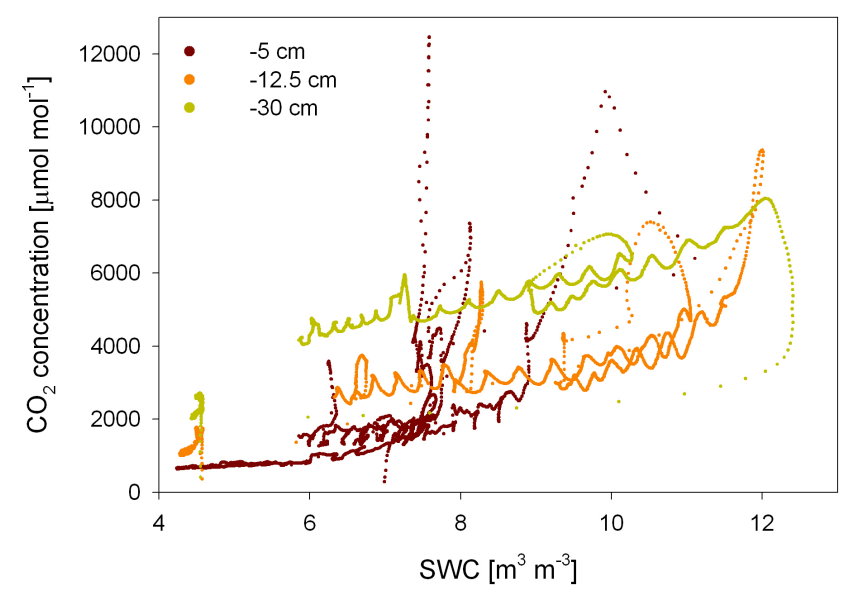

Fig. 5. Dependence of $\mathrm{CO}_{2}$ concentrations on volumetric soil water content at three measurement depths during the summer of 2009. Diurnal cycles (probably due to daily temperature changes) and occasional peaks of $\mathrm{CO}_{2}$ concentration (after rain events) are shown superposed on the relationship.

similar or higher values than chambers in natural vegetation gaps. Further differences between the treatments (trenching) were that fluxes from the non-trenched treatment responded to rain without delay, while fluxes from the trenched ones started to rise 6 to $9 \mathrm{~h}$ later (Fig. 6).

The soil respiration measurement system was operational during the summer of 2009 in spite of the large temperature range and precipitation events (Fig. 2), except for a period with electrical supply failure in July. Precipitation pulses caused respiration bursts (Potts et al., 2006, Baldocchi et al., 2006), demonstrated by both the eddy and the soil respiration systems. When pairing non-trenched $R_{\mathrm{sc}}$ data to nighttime eddy $R_{\text {eco }}$ data (applying $u^{*}$ filter of $0.1 \mathrm{~m} \mathrm{~s}^{-1}$ ), the relation proved to be statistically significant, and $R_{\text {eco }}$ in the low range (below $2 \mu \mathrm{mol} \mathrm{CO} \mathrm{CO}^{-2} \mathrm{~s}^{-1}$ ) was similar to or smaller than $R_{\mathrm{sc}}$ (Fig. 4). While the four chamber system (2 replications) might not provide enough data to characterize spatial variability, $R_{\mathrm{S}}$ data together with $R_{\mathrm{sc}}$ from the trenched plots may help to estimate the range of soil respiration.

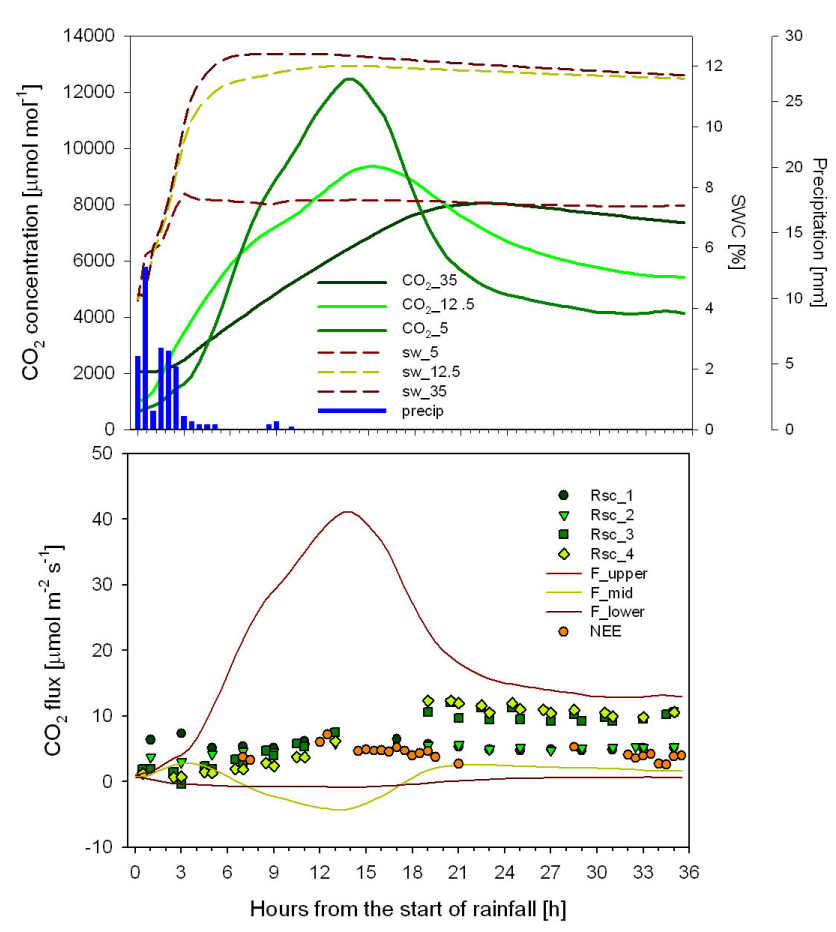

Fig. 6. Time course of $\mathrm{CO}_{2}$ concentrations at the three depths after a rain event (on the 4 August, also shown in Fig. 9). F_upper: $\mathrm{CO}_{2}$ flux between $5 \mathrm{~cm}$ depth and the surface, $\mathrm{F} \_$mid: $\mathrm{CO}_{2}$ flux between $12 \mathrm{~cm}$ and $5 \mathrm{~cm}$ depths, F_lower: $\mathrm{CO}_{2}$ flux between $35 \mathrm{~cm}$ and $12 \mathrm{~cm}$ depths, respectively. Rsc_1, Rsc_2, Rsc_3, Rsc_4 and NEE are the fluxes measured by the chambers and EC system, respectively.

\section{3 $\mathrm{CO}_{2}$ concentration dynamics in the soil profile and soil respiration as estimated by the gradient method}

$\mathrm{CO}_{2}$ concentration in the measured soil layers were dependent on the soil layer's wetness, with superimposed daily cycles (probably reflecting that of temperature) and occasional high $\mathrm{CO}_{2}$ concentrations after rain events (Fig. 5). After rainstorm events, the usual $\mathrm{CO}_{2}$ concentration gradients were reversed for several hours (Fig. 6). $\mathrm{CO}_{2}$ concentrations in the upper 5 -cm layer peaked at 3 to $7 \mathrm{~h}$ after rain, at 6 to $9 \mathrm{~h}$ in $12 \mathrm{~cm}$ depth and at 9 to $17 \mathrm{~h}$ in $30 \mathrm{~cm}$ depth and also several hours after SWC had already leveled off (Fig. 6). Tthe increase in $\mathrm{CO}_{2}$ concentration at a particular depth depended on the total precipitation sum brought by a rain event (Fig. 7) during the drought. A simple model, based on Eq. (1) and Eq. (2), was applied to calculate the relative contribution of diffusive limitation vs. $\mathrm{CO}_{2}$ production to $\mathrm{CO}_{2}$ concentration increases observed in the upper two layers after a rain event. Average $\mathrm{CO}_{2}$ production in a layer during the day prior to the rain event was calculated as the difference between the average (half hour) fluxes at the top and the bottom of a given layer. This pre-rain production rate was used as a constant in the model, while the same conductance ( $K$, Eq. 2$)$ values 


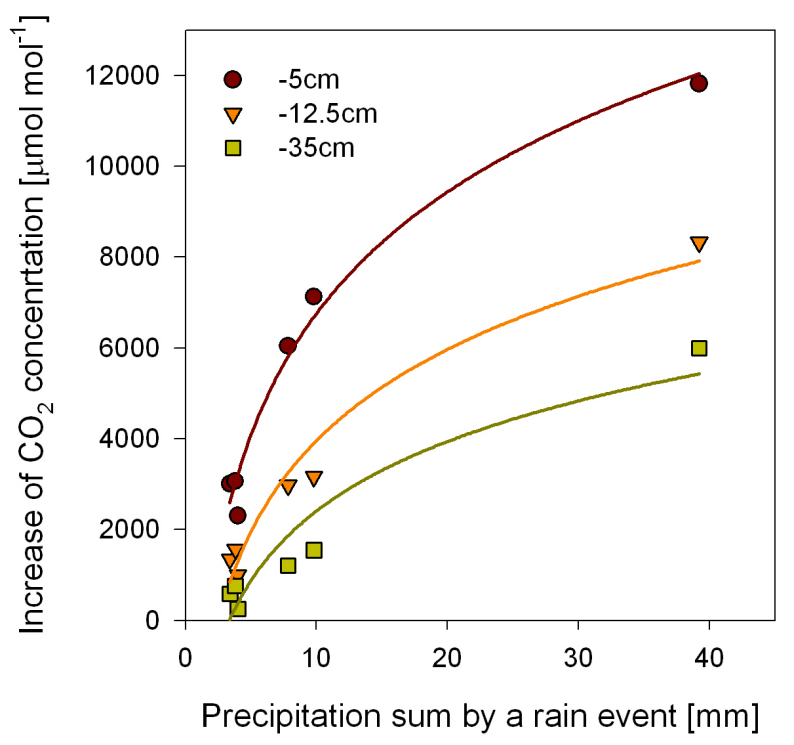

Fig. 7. Increase of $\mathrm{CO}_{2}$ concentration due to different precipitation sums after the summer drought period in August and start of September. Differences between $\mathrm{CO}_{2}$ concentration maxima (as measured after the rain events) and initial values of $\mathrm{CO}_{2}$ concentrations in the half hour prior to the rain at the three measurement depths are presented.

were used as for the calculation of the gradient fluxes. Simulated soil air $\mathrm{CO}_{2}$ concentrations in the upper two layers have been compared to the measured $\mathrm{CO}_{2}$ concentrations in the layers. The concentration ratio was considered as a measure of diffusive retardation. Decrease of $K$ alone after start of the rain event would have contributed to slightly less than $7 \%$ of $\mathrm{CO}_{2}$ concentration increase in the upper soil layer (Fig. 8), assuming pre-rain $\mathrm{CO}_{2}$ production levels at peak concentrations. This shows the share of enhanced respiration activity in the observed increase in $\mathrm{CO}_{2}$ concentration to be more than $90 \%$ (Fig. 8) at peak concentrations. However, overestimation of $K$ Eq. (2) by the gradient method during and after rains (rapid SWC changes, Fig. 8 inset) obviously modifies the relative magnitudes of the above limitations by increasing the effect of diffusive retardation.

Soil respiration, as estimated by the gradient method $\left(\mathrm{R}_{\mathrm{sg}}\right)$, strongly decreased with soil depth (Fig. 9). After precipitation events, during the dry summer $R_{\mathrm{sg}}$ within the soil profile had both up and downward components as calculated from the 5 and $12.5 \mathrm{~cm}$ sensor depths, respectively (Fig. 9). The downward $\mathrm{CO}_{2}$ fluxes were caused by a temporary reversal of $\mathrm{CO}_{2}$ concentration gradients that developed after rain events (Fig. 6, Fig. 9, Fig. 10). The longest continuous period of downward flux was 4.5 days, while the duration of downward fluxes (i.e. when both up and downward fluxes occurred) represented $11.4 \%$ of the measurement period. The magnitude of downward fluxes was $15 \%$ of upward fluxes occurring at the same time and $\sim 7.6 \%$ of the total upward

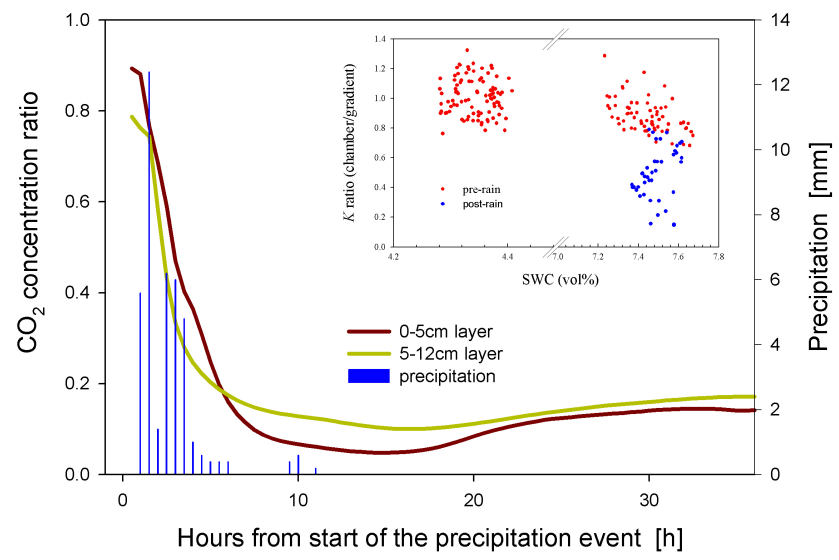

Fig. 8. Share of diffusion limitation in increase of $\mathrm{CO}_{2}$ concentration in a given layer after the start of a rain event (also shown in Fig. 6) in the upper $(0-5 \mathrm{~cm})$ and in the middle $(5-12 \mathrm{~cm})$ soil layer. Average diurnal pre-rain $\mathrm{CO}_{2}$ production level in the layers have been used in parallel with actual $K$ ( as estimated by Eq. 1) values. Diffusion limitation caused by the rain (decrease of air filled pore space) accounted for about $10 \%$ (middle layer), or less than $10 \%$ (upper layer) of the $\mathrm{CO}_{2}$ concentration increase, showing production as the main driver of $\mathrm{CO}_{2}$ concentration increase. Inset: Conductance $(K)$ values have been recalculated after replacing the estimated flux (Eq. 1) by chamber (Ch2) measurements. The ratio of the conductance values (from chamber/gradient fluxes, respectively) is shown in the function of volumetric soil water content in the upper $(5 \mathrm{~cm})$ soil layer for two $\mathrm{SWC}$ ranges. The rain event causes the ratio to strongly depart from 1.

flux within the 3-month period. The upper 5-cm soil layer contributed to $\sim 50 \%$ of the total $R_{\text {sg }}$ flux during the 4-month study period, shown in Fig. 9.

\subsection{Comparing fluxes measured by the gradient method $\left(R_{\mathrm{sg}}\right)$ to those measured by the open system's chambers $\left(R_{\mathrm{sc}}\right)$ and to the eddy fluxes}

$R_{\text {sg }}$ data collected during periods of (soil air) $\mathrm{CO}_{2}$ concentration gradient inversion after rain events (as shown in Fig. 6) were excluded from the comparison to parallel chamber efflux data. The regression between $R_{\mathrm{sg}}$ and $R_{\mathrm{sc}}$ was highly significant showing the intercept very close to and not significantly different from 0 (Fig. 11). This also may serve as an independent check of the calibration of the chamber flux system at zero efflux, since it shows that the chamber system would measure zero efflux at concentration gradients approaching zero (the likely situation when the gradient system will measure zero). $R_{\mathrm{sg}}$ values were higher than the $R_{\mathrm{sc}}$ (considering the two chambers' data from the untrenched treatment). While spatial heterogeneity of soil $\mathrm{CO}_{2}$ efflux might well have caused the difference between the two chambers, overestimation of soil respiration by the gradient method is suggested as $R_{\mathrm{sc}}$ values were calibrated against an independent flux measurement (i.e. the efflux from the calibration 


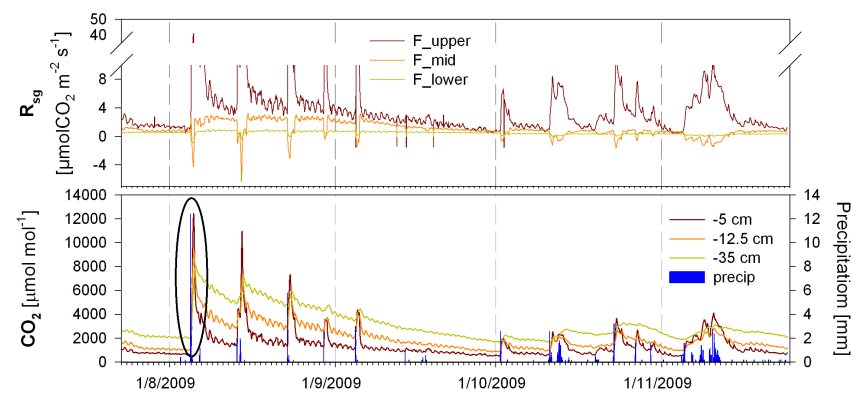

Fig. 9. Time course of soil respiration rates at three soil depths (see Table 2.) during drought in summer and autumn recovery (downward fluxes have negative signs, upper graph), $\mathrm{CO}_{2}$ concentration within the soil profile at $5,12.5$ and $35 \mathrm{~cm}$ below ground, respectively, and course of precipitation events (lower graph).

tank). $R_{\mathrm{sg}}$ from the upper soil layer was significantly correlated to $u^{*}$-filtered eddy (daytime uptake and nighttime $R_{\text {eco }}$ fluxes (Fig. 12), too. Rain events led to unrealistically high $R_{\text {sg }}$ estimates.

\section{Discussion}

\subsection{Characteristics of the soil respiration system}

The chamber system for soil respiration measurement was successfully calibrated against known $\mathrm{CO}_{2}$ effluxes in the lab, and demonstrated reliable performance in the field. The main advantages of the new system are the minor disturbance to the soil structure and the spatial structure of the vegetation and the possibility for continuing long-term, unattended measurements of soil $\mathrm{CO}_{2}$ efflux. Avoiding disturbance of vegetation spatial structure is thought to be important because this structure might have been formed over years and patches with different vegetation cover are expected to behave differently, considering the dependence of soil respiration on current photosynthesis (Högberg et al., 2001, Tang et al., 2005b), for example. When applying larger chambers, the disturbance of the vegetation spatial structure (i.e. partial or complete removal of vegetation in order to have enough space to insert the chamber) is expected to disturb also the relative weights of processes contributing to soil respiration (i.e. root respiration, microbial respiration). A disadvantage of the system operating in the same place for extended periods is that it may potentially alter the temperature and water content of the soil under the chamber, causing it to differ from that of the surrounding soil. On the other hand, the chambers are insulated against radiation (outer white cylinder), they are ventilated during measurements, there are vent holes on the top of the chambers (also allowing precipitation water to enter the chamber) and the radius of the chamber is $2.5 \mathrm{~cm}$. Any gradient of the driving variables (i.e. soil temperature and water content) developing from inside will be

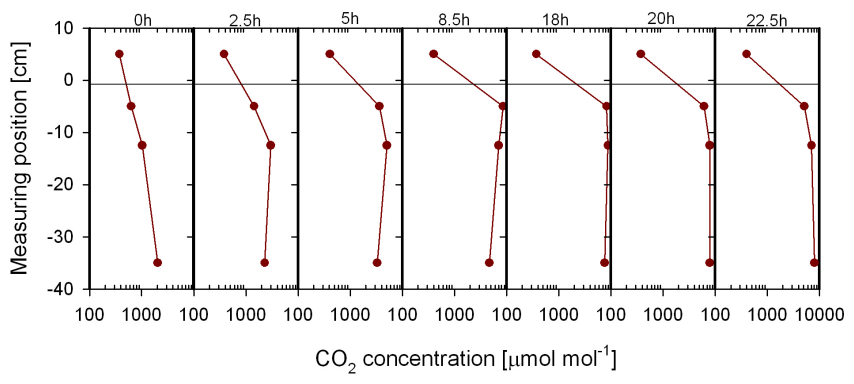

Fig. 10. $\mathrm{CO}_{2}$ concentration profiles within (and $5 \mathrm{~cm}$ above) the soil after the start of a larger rain event on 4th of August (also shown in Fig. 6).

balanced from outside and from below at that scale $(2.5 \mathrm{~cm})$. One further disadvantage of the system in its present setup is that it does not manage the problem of spatial variability of soil respiration. The size of the eddy flux footprint is larger by several orders of magnitude than the area covered by the soil respiration chamber. Using larger chambers (diameter of $10 \mathrm{~cm}$, for example) would probably not mitigate this problem much. The deployment of more chambers and geostatistical analysis of the data may help on the scale problem by providing the average patch diameter (as inferred from semivariogram analysis) for soil respiration. The spatial range associated with semivariance maximum of $R_{\mathrm{S}}$ data for the Bugac grassland was found to be between $0.8 \mathrm{~m}$ to $4 \mathrm{~m}$ depending on season and the water availability (Fóti et al., 2008), suggesting that average soil respiration of a patch/area of this diameter can be considered as spatially representative for this grassland.

$R_{\mathrm{sc}}$ data from the trenched plot were used in this study as a lower baseline value for soil respiration. While estimating the upper limit of the $R_{\mathrm{S}}$ range is not possible on the basis of the present data, other measurements of soil respiration at the Bugac site (Balogh et al. 2011) gave the same range as that measured by the new system.

The $R_{\mathrm{sc}}$ average from trenched plots was generally lower than $R_{\mathrm{sc}}$ from the chambers placed within natural vegetation gaps (between grass tufts); this was probably due to a lack of fresh carbon supply, even if the soil surface temperature (which was probably higher in the trenched plots not shaded by the grass) may have favored higher soil respiration rates. After rain events, however, chambers in the trenched plots measured similar or higher values than chambers in natural vegetation gaps. As rain interception by the canopy was probably non-zero in vegetated plots, while it was zero in the trenched plots, different rain intensities (higher in the trenched plots) might have caused the fluxes running higher in the trenched plots than in the not trenched ones after rains. $R_{\mathrm{sc}}$ in the trenched treatment started to respond to rain by 6 to $9 \mathrm{~h}$ later than $R_{\mathrm{sc}}$ in the not trenched treatment (Fig. 6). While the background of difference in response dynamics is unclear, it might have been related to the amount and 


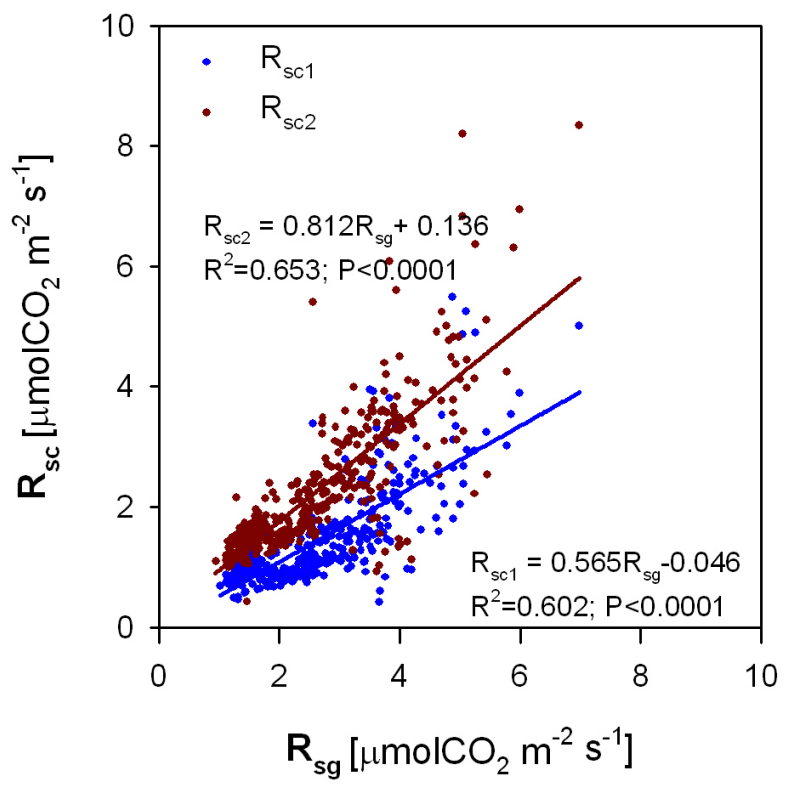

Fig. 11. Soil respiration as measured by the gradient method at the surface $\left(R_{\mathrm{Sg}}\right)$ vs. $\mathrm{R}_{\mathrm{Sc}}$ (non-trenched, data sets of the two chambers are separated, $\mathrm{R}_{\mathrm{sc} 1}$ and $\left.\mathrm{R}_{\mathrm{sc} 2}\right)$. Paired $\left(R_{\mathrm{sg}}\right.$ and $\left.R_{\mathrm{Sc}}\right)$ data were used for fitting. $R_{\mathrm{sg}}$ data during periods of inversion of the concentration gradients within the soil profile (after rains) were excluded from the regression.

distribution of subsurface litter as caused by the trenching (and packing back) procedure. Further plausible explanation is the lack of response by roots in the trenched plots, i.e. root and rhizospheric respiration may respond sooner to wetting than the other respiration components.

\subsection{Comparison of different methods for measuring soil $\mathrm{CO}_{2}$ efflux}

Nighttime $R_{\text {eco }}$ as measured by the eddy system was in many cases smaller than soil respiration measured by the automated chamber system $\left(R_{\mathrm{sc}}\right)$, but the differences were smaller than the sum of the uncertainty estimates for the two fluxes. The analysis was carried out using $u^{*}$ filtered and storage corrected eddy flux data. Nighttime flux losses frequently result from low turbulence conditions (56\% with $u^{*}$ threshold of $0.1 \mathrm{~ms}^{-1}$ in the investigated period). Applying higher $u^{*}$ thresholds, on the other hand leads to even larger fraction of flux losses. Underestimation of night fluxes has also been observed in other studies (Goulden et al., 1996, van Gorsel et al., 2007, Myklebust et al., 2008). Spatial heterogeneity of fluxes, and unaccounted storage are among the candidates, the latter showing up as a build-up of $\mathrm{CO}_{2}$ below the level of measurement (Fig. 13) during still nights, a situation that can be common in the plains over smooth and flat surfaces (Smith et al., 2010). While measurements over flat terrain may be less prone to advection (Osborne et al., 2010), low atmospheric turbulence conditions can be-

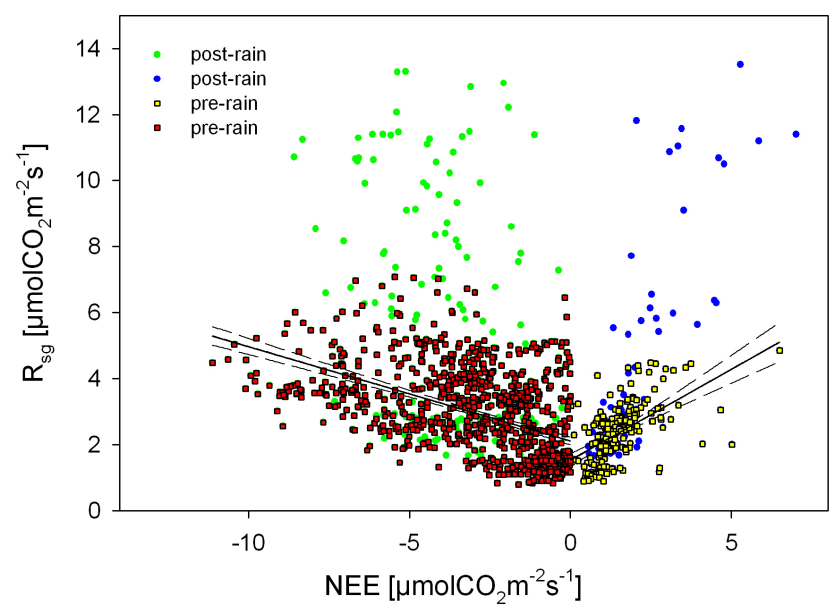

Fig. 12. Gradient flux from the upper soil layer $\left(R_{\mathrm{sg}}\right)$ in the function of pre- and post-rain daytime uptake and nighttime Reco values, respectively (data from periods without rain in the preceeding $36 \mathrm{~h}$ were considered as pre-rain). Eddy data have been $u^{*}$-filtered $\left(u^{*}>0.1 \mathrm{~ms}^{-1}\right)$. Regressions lines (and confidence intervals) are shown for the pre-rain values. Regression statistics for pre-rain data are shown in Table 5.

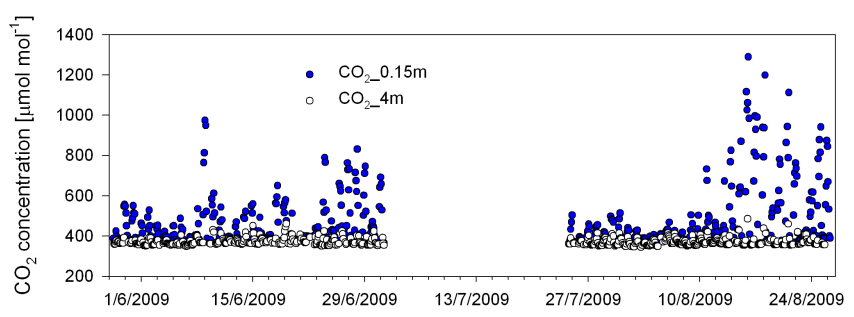

Fig. 13. $\mathrm{CO}_{2}$ concentrations at the eddy measurement height $(4 \mathrm{~m})$ and at $0.15 \mathrm{~m}$ above ground level, respectively.

come more significant in affecting storage (Haszpra et al., 2005; Smith et al., 2010). The above limitation of the eddy technique at localities where low turbulence conditions are frequent may necessitate application of measurements, independent of the eddy system for measuring soil $\mathrm{CO}_{2}$ effluxes. One possible solution to the problem of low nighttime $R_{\text {eco }}$ fluxes is that of multiple constraints, when independent measurements are considered in parallel (Myklebust et al., 2008). To date, chamber measurements are the most direct way of determining $R_{\mathrm{s}}$, although conductance within the chamber is undoubtedly different from that outside the chamber (Balogh et al., 2007).

The gradient method demonstrated higher fluxes of soil respiration than those measured by the open system $\left(R_{\mathrm{sg}}>R_{\mathrm{sc}}\right)$. The regression between the two, physically independent systems was highly significant, except around rain events. These events may differently affect the tortuosity and connectedness of the soil diffusion paths at different depths (e.g. advance of the wetting front), thereby causing 
Table 5. Statistics of linear regressions between $R_{\text {sg }}$ and NEE (see Fig. 12).

\begin{tabular}{llccc}
\hline Data selection & Coefficients & & SE of coefficients & P value \\
\hline \multirow{3}{*}{ Pre-rain (x: night $R_{\text {eco }}$ ) } & Intercept & 1.531 & 0.103 & $<0.0001$ \\
& Slope & 0.551 & 0.060 & $<0.0001$ \\
& $R^{2}=0.311$ & & & $<0.0001$ \\
\hline \multirow{2}{*}{ Pre-rain (x: daytime uptake) } & Intercept & 2.111 & 0.062 & $<0.0001$ \\
& Slope & -0.286 & 0.017 & $<0.0001$ \\
& $R^{2}=0.256$ & & & $<0.0001$ \\
\hline
\end{tabular}

uncertainty (overestimation) of conductance. Overestimation of soil $\mathrm{CO}_{2}$ efflux at the soil surface by the gradient method is suggested also, because $R_{\mathrm{sc}}$ values (compared to parallel $R_{\text {sg }}$ data) were calibrated against an independent flux measurement (i.e. the efflux from the calibration tank). One possible explanation for the deviation between the two methods is the error in the calculated conductance values. This error, in turn, may likely have arisen in part from the tortuosity factor estimates based on the silt and clay fractions (Tang et al., 2005a). Overestimation of $K$ by the gradient method after the start of the rain event, was probably also related to the vertical distribution of soil water. The average soil water content (as measured by the horizontally placed CS616 sensor) will necessarily differ from the highest SWC in the layer, setting the limit for $K$. Eq. (2). assumes steady state conditions, which are unlikely to persist during rapid SWC changes. Gradient fluxes demonstrated greater increases after rain events than chamber fluxes. Consequently, the calculated conductance values are probably in error during these periods. Diffusive retardation after rains explained less than $10 \%$ of the observed increases in soil air $\mathrm{CO}_{2}$ concentration in the upper soil layer showing dominance $\mathrm{CO}_{2}$ production in concentration increase.

The strong correlation between $R_{\mathrm{sc}}$ and $R_{\mathrm{sg}}$ values suggests that after a longer period of continuous parallel operation, $R_{\mathrm{sc}}$ value could be used to scale $R_{\mathrm{sg}}$ by adjusting the tortuosity value (parameter $S$ in Eq. 2) and by considering (modeling) the vertical distribution of SWC at finer spatial (vertical) resolution. This latter aspect can be critical during rapid SWC changes (after rains). Soil fluxes estimated by the soil gradient method were strongly correlated to eddy fluxes. Rain effect (high $K$ values) showed up in the repsonses in this case, too.

\subsection{Implications for partitioning fluxes}

The inversion of the usual (downward increasing) $\mathrm{CO}_{2}$ concentration gradient within the soil profile resulted in $\mathrm{CO}_{2}$ fluxes of downward direction. The magnitude of these downward fluxes are interesting since the $\mathrm{CO}_{2}$ carried by these fluxes will start to efflux from the soil possibly several hours (or even days) later. Fluxes within the soil pro- file of downward direction occurring after rains (interrupting serious droughts) amounted to $15 \%$ of the simultaneous upward fluxes and to $\sim 7.6 \%$ of the total (upward) effluxes during the 3-month study. The longest (continuous) downward flux lasted for 4 and a half days, with an average intensity of $\sim 1 \mu \mathrm{mol} \mathrm{CO} \mathrm{m}^{-2} \mathrm{~s}^{-1}$, when the upward $R_{\mathrm{S}}$ flux was in the range of 4 to $6 \mu \mathrm{mol} \mathrm{CO} \mathrm{m}^{-2} \mathrm{~s}^{-1}$ (Fig. 9). This (downward) component, together with the wind shear dependent storage flux component (Hirsch et al., 2004), may seriously affect $R_{\text {eco }}$ estimates (Flechard et al., 2005, van Gorsel et al., 2007, Myklebust et al., 2008), with obvious effect on the apparent temperature dependence of $R_{\text {eco }}$. A percentage of soil respiration-derived $\mathrm{CO}_{2}$ was only detectable by the eddy or chamber system significantly after the respiration process took place in the soil layers. This situation led to a temporal decoupling of above- and belowground respiration processes. The decoupling of $R_{\text {eco }}$ components is not important when considering that the $\mathrm{CO}_{2}$ transported downward will finally efflux from the soil and the carbon balance of the surface will be valid in the longer term. The decoupling of $R_{\text {eco }}$ components (surface vs. ecosystem fluxes) may become important, however, when considering partitioning and gap filling procedures, usually working at half-hourly time steps. The phenomena (and determining the possible relative magnitude) of downward respiratory fluxes is likely of general importance in seriously water-limited ecosystems.

\section{Conclusions}

The open system developed for measuring soil respiration was successfully calibrated against effluxes from a calibration tank. The new system measured soil $\mathrm{CO}_{2}$ effluxes for months without malfunction.

Notable findings from the present study are that: (1) Independent measurements of $R_{\mathrm{S}}$ by the open system chamber and the gradient technique were significantly correlated to each other and to the eddy fluxes; (2) gas phase conductance values (gradient method) are overestimated during rapid soil water content changes after rains; (3) downward fluxes of respiratory origin in drought-stressed grasslands may be common after rainstorms; (4) soil air $\mathrm{CO}_{2}$ 
concentration increase strongly depends on rainfall amount; (5) diffusion limitation plays a smaller role than $\mathrm{CO}_{2}$ production in $\mathrm{CO}_{2}$ concentration build up in the upper soil layers after rains. However, overestimated conductance $(K)$ values during rains show a serious limitation of the gradient method in this respect. Using several soil water content sensors in a way to give finer spatial resolution of vertical SWC distribution as well as new models describing the diffusion limitations in more detail (Koehler et al., 2010) may help in addressing this problem. The difference between observed surface and real time ecosystem fluxes can lead to increased uncertainties in the calculated C-balances at hourly and daily scales and also when applying gap-filling functions and/or procedures. The problem lies in the temporal lag between production and efflux of $\mathrm{CO}_{2}$ from the soil. As with the balance, increasing the averaging time might be considered as a solution. However, the lag is generally not considered when fitting $R_{\text {eco }}$ against $T_{\mathrm{S}}$ in subsequent use for gap filling purposes. While neglecting this time lag may be acceptable when calculating surface fluxes in general, it is probably not so in cases where downward fluxes of varying durations and intensities occur within the soil profile. The probability of these events is high after rains in an otherwise dry period. These situations are responsible for significant $\mathrm{CO}_{2}$-fluxes in dry ecosystems (Xu et al., 2004), demonstrating the necessity of a better description of the component processes. The $15 \%$ share of downward fluxes within the soil profile as experienced during and immediately after rain events in this study seems to be large enough to seriously affect gap filling procedures. The strong correlation between data, measured by independent systems, shows the possible utility of these systems to the multiple constraints approach.

Acknowledgements. The authors gratefully acknowledge the financial support of the following foundations and research programs: Hungarian national projects (OTKA-K75638, TAMOP 4.2.2, REGKM-INFRA-09), Nitroeurope IP (017810-2), Animal Change (FP7 266018), Hungarian-Czech Science and Technology Foundation (TéT-CZ 2/2006), CzechGlobe Centre (CZ.1.05/1.1.00/02.0073), and OC08021 from ME of CR.

Edited by: P. Stoy

\section{References}

Aubinet, M., Chermanne, B., Vandenhaute, M., Longdoz, B., Yernaux, M., and Laitat, E.: Long term carbon dioxide exchange above a mixed forest in the Belgian Ardennes, Agric Forest Meteorol., 108(4) 293-315, 2001.

Bahn, M., Rodeghiero, M., Anderson-Dunn, M., Dore, S., Gimeno, C., Drösler, M., Williams, M., Ammann, C., Berninger, F., Flechard, C., Jones, S., Balzarolo, M., Kumar, S., Newesely, C., Priwitzer, T., Raschi, A., Siegwolf, R., Susiluoto, S., Tenhunen, J., Wohlfahrt, G., and Cernusca, A.: Soil Respiration in
European Grasslands in Relation to Climate and Assimilate Supply, Ecosystems, 11, 1352-1367, 2008.

Baldocchi, D., Tang, J., and Xu, L.: How switches and lags in biophysical regulators affect spatial-temporal variation of soil respiration in an oak-grass savanna, J. Geophys. Res., 111, G02008, doi:10.1029/2005JG000063, 2006.

Balogh, J., Nagy, Z., Fóti, Sz., Pintér, K., Czóbel, Sz., Péli, E. R., Acosta, M., Marek, M. V., Csintalan, Zs., and Tuba, Z.: Comparison of $\mathrm{CO}_{2}$ and $\mathrm{H}_{2} \mathrm{O}$ fluxes over grassland vegetations measured by the eddy-covariance technique and by open system chamber, Photosynthetica, 45(2), 288-292, 2007.

Balogh, J., Pintér K., Fóti, Sz., Papp, M., Cserhalmi, D., and Nagy, Z.: Dependence of soil respiration on soil moisture, clay content, soil organic matter and $\mathrm{CO}_{2}$ uptake in dry grasslands, Soil Biol. Biochem., 43, 1006-1013, doi:10.1016/j.soilbio.2011.01.017, 2011.

Barcza, Z., Haszpra, L., Kondo, H., Saigusa, N., Yamamoto, S., and Bartholy, J.: Carbon exchange of grass in Hungary, Tellus B, 55, 187-196, 2003.

Cao, G., Tang, Y., Mo, W., Wang, Y., Li, Y., and Zhao, X.: Grazing intensity alters soil respiration in an alpine meadow on the Tibetian Plateau, Soil Biol. Biochem., 36, 237-243, 2004.

Fang, C. and Moncrieff, J. B.: An improved dynamic chamber technique for measuring $\mathrm{CO}_{2}$ efflux from the surface of soil, Funct. Ecol., 10, 297-305, 1996.

Fang, C. and Moncrieff, J. B.: An open-top chamber for measuring soil respiration and the influence of pressure difference on $\mathrm{CO}_{2}$ efflux measurement, Funct. Ecol., 12, 319-325, 1998.

Flanagan, L. B., Wever, L. A., and Carlson, P. J.: Seasonal and interannual variation in carbon dioxide exchange and carbon balance in a northern temperate grassland, Glob. Change Biol., 8, 599615, 2002.

Flechard, C. R., Neftel, A., Jocher, M., Ammann, C., Leifeld, J., and Fuhrer, J.: Temporal changes in soil pore space $\mathrm{CO}_{2}$ concentration and storage under permanent grassland, Agric. Forest Meteorol., 142, 66-84, 2007.

Fóti, Sz., Balogh, J., Nagy, Z., Bartha, S., Ürmös, Zs., and Tuba, Z.: Temporal and spatial variability and pattern of soil respiration in loess grassland, Community Ecol., 9, 57-64, 2008.

van Gorsel, E., Leuning, R., Cleugh, H. A., Keith, H., and Suni, T.: Nocturnal carbon efflux: reconciliation of eddy covariance and chamber measurements using an alternative to the $\mathrm{u}(*)$-threshold filtering technique, Tellus B, 59, 397-403, 2007.

Goulden, M. L., Munger, J. W., Fan, S. M., Daube, B. C., and Wofsy, S. C.: Measurements of carbon sequestration by longterm eddy covariance: Methods and a critical evaluation of accuracy, Glob. Change Biol., 2, 169-182, 1996.

Haszpra, L., Barcza, Z., Davis, K. J., and Tarczay, K.: Long-term tall tower carbon dioxide flux monitoring over an area of mixed vegetation, Agric. Forest Meteorol., 132, 58-77, 2005.

Hirsch, A. I., Trumbore, S. E., and Goulden, M. L.: The surface $\mathrm{CO}_{2}$ gradient and pore-space storage flux in a high-porosity litter layer, Tellus B, 56, 312-321, 2004.

Högberg, P., Nordgren, A., Buchmann, N., Taylor, A. F. S., Ekblad, A., Högberg, M. N., Nyberg, G., Ottosson-Löfvenius, M., and Read, D. J.: Large-scale forest girdling shows that current photosynthesis drives soil respiration, Nature, 411, 789-792, 2001.

Hollinger, D. Y. and Richardson A. D.: Uncertainty in eddy covariance measurements and its application to physiological models, 
Tree Physiol., 25, 873-885, 2005.

Hook, P. B., Lauenroth, W. K., and Burke, I. C.: Spatial patterns of roots in a semiarid grassland: abundance of canopy openings and regeneration gaps, J. Ecol., 82, 485-494, 1994.

Iritz, Z., Lindroth, A., and Gärdenäs, A.: Open ventilated chamber system for measurements of $\mathrm{H}_{2} \mathrm{O}$ and $\mathrm{CO}_{2}$ fluxes from the soil surface, Soil Technol., 10, 169-184, 1997.

Janssens, A., Lankreijer, H., Matteucci, G., Kowalski, A. S., Buchmann, N., Epron, D., Pilegaard, K., Kutsch, W., Longdoz, B., Grünwald, T., Montagnani, L., Dore, S., Rebmann, C., Moors, E. J., Grelle, A., Rannik, Ü., Morgenstern, K., Oltchev, S., Clement, R., Guðmundsson, J., Minerbi, S., Berbigier, P., Ibrom, A., Moncrieff, J., Aubinet, M., Bernhofer, C., Jensen, N. O., Vesala, T., Granier, A., Schulze, E.-D., Lindroth, A., Dolman, A. J., Jarvis, P. G., Ceulemans, R., and Valentini, R.: Productivity overshadows temperature in determining soil and ecosystem respiration across European forests, Glob. Change Biol., 7, 269-278, 2002.

Jones, H. G.: Plants and Microclimate: A Quantitative Approach to Environmental Plant Physiology, Cambridge University Press, New York, 1992.

Koehler, B., Zehe, E., Corre, M. D., and Veldkamp, E.: An inverse analysis reveals limitations of the soil- $\mathrm{CO}_{2}$ profile method to calculate $\mathrm{CO}_{2}$ production and efflux for well-structured soils, Biogeosciences, 7, 2311-2325, doi:10.5194/bg-7-2311-2010, 2010.

Luo, Y. and Zhou, X.: Soil respiration and the environment. Burlington, MA and San Diego, CA, USA, Academic Press, 2006.

Massman, W. J. and Lee, X.: Eddy covariance flux corrections and uncertainties in long-term studies of carbon and energy exchanges, Agric. Forest Meteorol., 113, 121-144, 2002.

Moldrup, P., Olesen T., Yamaguchi, T., Schjønning, P., and Rolston, D. E.: Modeling diffusion and reaction in soils: VIII. Gas diffusion predicted from single-potential diffusivity or permeability measurements, Soil Sci., 164, 75-81, 1999.

van der Molen, M. K., Gash, J. H. C., and Elbers, J. A.: Sonic anemometer (co)sine response and flux measurement - II. The effect of introducing an angle of attack dependent calibration, Agric. Forest Meteorol., 122, 95-109, 2004.

Moore, C. J.: Frequency-response corrections for eddy-correlation systems, Bound-Lay. Meteorol., 37, 17-35, 1986.

Myklebust, M. C., Hipps, L. E., and Ryel, R. J.: Comparison of eddy covariance, chamber, and gradient methods of measuring soil $\mathrm{CO}_{2}$ efflux in an annual semi-arid grass, Bromus tectorum, Agric. Forest Meteorol., 148, 1894-1907, 2008.

Nagy, Z., Pintér, K., Czóbel, Sz., Balogh, J., Horváth, L., Fóti, Sz., Barcza, Z., Weidinger, T., Csintalan, Zs., Dinh, N. Q., Grosz, B., and Tuba, Z: The carbon budget of a semiarid grassland in a wet and a dry year in Hungary, Agr. Ecosyst. Environ., 121, 21-29, 2007.

Pintér, K., Nagy, Z., Barcza, Z., Balogh, J., Czóbel, Sz., Csintalan, Zs., and Tuba, Z.: Interannual variability of grasslands' carbon balance depends on soil type, Community Ecol., 9, 43-48, 2008.
Osborne, B., Saunders, M., Walmsley, D., Jones, M., and Smith, P.: Key questions and uncertainties associated with the assessment of the cropland greenhouse gas balance, Agr. Ecosyst. Environ., 139(3), 293-301, 2010.

Potts, D. L., Huxma, T. E., Enquis, B. J., Weltzin, J. F., and Williams, D. G.: Resilience and resistance of ecosystem functional response to a precipitation pulse in a semi-arid grassland, J. Ecol., 94, 23-30, 2006.

Pumpanen, J., Kolari, P., Ilvesniemi, H., Minkkinen, K., Vesala T., Niinistö, S., Lohila, A., Larmola, T., Morero, M., Pihlatie, M., Janssens, I., Yuste, J. C., Günzweig, J. M., Reth, J. A., Subke, K., Savage, W., Kutsch, G., Østreng, W., Ziegler, P., Anthony, A., Lindroth, S., and Hari, P.: Comparison of different chamber techniques for measuring soil $\mathrm{CO}_{2}$ efflux, Agric. Forest Meteorol., 123, 159-176, 2004.

Raich, J. W. and Schlesinger, W. H.: The global carbon dioxide flux in soil respiration and its relationship to vegetation and climate, Tellus B, 44(2), 81-99, 1992.

Smith, P., Lanigan, G., Kutsch, W. L., Buchmann, N., Eugster, W., Aubinet, M., Ceschia, E., Béziat, P., Yeluripati, J. B., Osborne, B., Moors, E. J., Brut, A., Wattenbach, M., Saunders, M., and Jones, M.: Measurements necessary for assessing the net ecosystem carbon budget of croplands, Agr. Ecosyst. Environ., 139(3), 302-315, 2010.

Subke, J.-A., Inglima, I., Peressotti, A., Vedove, G. D., and Cotrufo, M. F.: A new technique to measure soil $\mathrm{CO}_{2}$ efflux at constant $\mathrm{CO}_{2}$ concentration, Soil Biol. Biochem., 36, 1013-1015, 2004.

Tang, J., Baldocchi, D., Qi, Y., and Xu, L.: Assessing soil $\mathrm{CO}_{2}$ efflux using continuous measurements of $\mathrm{CO}_{2}$ profiles in soils with small solid state sensors, Agric. Forest Meteorol., 118, 207 220, 2003.

Tang, J., Misson, L., Gerhenson, A., Cheng, W., and Goldstein, A. H.: Continuous measurements of soil respiration with and without roots in a ponderosa pine plantation in the Sierra Nevada Mountains, Agric. Forest Meteorol., 132, 212-227, 2005a.

Tang, J. W., Baldocchi, D. D., and Xu, L.: Tree photosynthesis modulates soil respiration on a diurnal time scale, Glob. Change Biol., 11, 1298-1304, 2005b.

Vickers, D. and Mahrt, L.: Quality control and flux sampling problems for tower and aircraft data, J. Atmos. Ocean. Tech., 14, 512526, 1997.

Wang, W. J., Zu, Y. G., Wang, H. M, Hirano, T., Takagi, K., Sasa, K., and Koike, T.: Effect of collar insertion on soil respiration in a larch forest measured with a LI-6400 soil $\mathrm{CO}_{2}$ flux system, J. Forest Res-Jpn., 10, 57-60, 2005.

Webb, E. K., Pearman, G. I., and Leuning, R.: Correction of flux measurements for density effects due to heat and water-vapor transfer, Q. J. Roy. Meteor. Soc., 106, 85-100, 1980.

Wilczak, J. M., Oncley, S. P. and Stage, S. A.: Sonic anemometer tilt correction algorithms, Bound-Lay. Meteorol., 99, 127-150, 2001.

Xu, L. K., Baldocchi, D. D., and Tang, J. W.: How soil moisture, rain pulses, and growth alter the response of ecosystem respiration to temperature, Global Biogeochem. Cy., 18(4) GB4002, doi:10.1029/2004GB002281, 2004. 